\title{
Purification and Biophysical Characterization of Hepatitis B Antigen
}

\author{
Chung Yong Kim and Jeremiah G. Tilles \\ From the Thorndike Memorial Laboratory; Harvard Medical Services, Boston \\ City Hospital, Boston 02118; and the Department of Medicine, Harvard \\ Medical School, Boston, Massachusetts 02115
}

A B S T R A C T Hepatitis B antigen ( $\mathrm{HB} \mathrm{Ag}$ ) has been purified from serum by pepsin digestion and equilibrium sedimentation. The sedimentation coefficient, density, particle size, and electrophoretic mobility have been determined before and after purification and found to be unaltered. In addition, the diffusion constant and molecular weight of purified $\mathrm{HB} \mathrm{Ag}$ have been documented.

Because the biophysical characteristics found are not consistant with those of any known virus, it is believed that native $\mathrm{HB} \mathrm{Ag}$ is made up almost entirely of incomplete virus.

\section{INTRODUCTION}

Hepatitis $\mathrm{B}$ antigen $(\mathrm{HB} \mathrm{Ag})^{1}$ was first demonstrated (1) in the blood of an Australian aborigine during a search for new immunoreactive substances. Current interest in the antigen centers around the possibility that it is either the virus of long incubation period hepatitis or a virus-associated antigen (2-10).

A determination of the biophysical properties of $\mathrm{HB}$ Ag should help in establishing its true identity. It is expected that the more pure the preparation the more reliable will be the biophysical data obtained. Several attempts to purify $\mathrm{HB} \mathrm{Ag}$ have utilized isopycnic banding or column and ion-exchange chromatography. However, when careful search has been made, serum protein contaminants have usually been demonstrated in the final solution $(6,7,11)$. A more successful recent study utilized isopycnic and rate-zonal sedimentation (12).

Received for publication 29 June 1971 and in revised form 4 December 1971.

${ }^{1}$ Abbreviations used in this paper: $\mathrm{HB} \mathrm{Ag}$, herpatitis $\mathrm{B}$ antigen; PAS, periodic acid fuchsin sulfite; PBS-EDTA, phosphate-buffered saline-ethylenediaminetetracetic; SDS, sodium dodecyl sulfate.
The present report describes a method for separation of the antigen from human serum proteins based on its relative resistance to pepsin digestion. Additional purification includes equilibrium sedimentation on both sucrose and cesium chloride density gradients. The biophysical findings of both native $\mathrm{HB} \mathrm{Ag}$ and the pure particle are presented and this information is used to characterize $\mathrm{HB}$ Ag.

\section{METHODS}

\section{Buffer}

Phosphate-buffered saline (PBS) plus ethylenediaminetetraacetic (EDTA) (Sorensen's $M / 15$ phosphate buffer with $\mathrm{pH}$ of 7.8 , containing $0.85 \% \mathrm{NaCl}$ and $0.001 \mathrm{M}$ disodium EDTA: PBS-EDTA) was found to prevent aggregation and therefore was used as the standard buffer.

\section{Antigen}

Source. HB Ag positive serum or plasma was obtained from patients with acute viral hepatitis. Control serum for the purification procedures came from a patient with acute fulminant hepatitis who was $\mathrm{HB} \mathrm{Ag}$ negative.

Identification. Standard double diffusion precipitin tests were carried out in a Gelman diffusion set using $0.9 \%$ agarose in PBS-EDTA supplemented with $0.01 \%$ sodium azide. The antigen was quantified with the modification of the standard technique described previously $(13,14)$.

\section{Antibody}

Sera containing antibody against $\mathrm{HB} \mathrm{Ag}$ were collected from patients with hemophilia who had received multiple transfusions. The sera were shown to have precipitin lines of identity with anti-HB Ag reference sera supplied by Dr. B. Blumberg.

\section{Pepsin digestion}

The sample was diluted 10 -fold with $0.02 \%$ pepsin (Worthington Biochemical Corp., Freehold, N. J.) in 0.02 $\mathrm{N} \mathrm{HCl} \mathrm{(with} \mathrm{approximate} \mathrm{enzyme} \mathrm{to} \mathrm{substrate} \mathrm{ratio} \mathrm{of} 1$ to 100$)$. The $\mathrm{pH}$ was adjusted to 2.3 and the mixture incubated at $37^{\circ} \mathrm{C}$ for varying intervals. 
Pepsin digested samples were dialyzed against the standard buffer at $4^{\circ} \mathrm{C}$ overnight before concentration to the original volumes by dialyzing against $20 \%$ carbowax (polycthylene glycol, Union Carbide Corp., New York) in PBS-EDTA. A similarly treated sample minus pepsin was used as control.

Polyacrylamide gel disc electrophoresis (Canalco standard method)

Electrophoresis was carried out under the following conditions: stacking gel, $\mathrm{pH} 6.8$; separating gel, $7 \%$ polyacry $1-$ amide (except where noted) with $\mathrm{pH} 8.8$; electrode buffer, cold tris (hydroxymethyl) aminomethane (Tris)-glycerine solution with $\mathrm{pH} 8.4$; and current, $5 \mathrm{~mA}$ /column for 40 min at room temperature.

\section{Gel electrophoresis and immunoelectrophoresis}

For both gel electrophoresis and immunoelectrophoresis, the supporting medium on microscope slides had a thickness of $1.5 \mathrm{~mm}$ and consisted of either $1 \%$ agarose or agar in Tris-barbital-sodium barbital buffer with $\mathrm{pH}$ of 8.8 and ionic strength of 0.05 . The electrodes had a diethyl barbiturate-acetate buffer with $\mathrm{pH}$ of 8.2 and ionic strength of 0.1 . Electrophoresis was carried out with a field strength of $15 \mathrm{~V} / \mathrm{cm}$ for $140 \mathrm{~min}$ at room temperature. Each gel was fixed in an alcohol-glacial acetic acid solution and dried before staining for protein. For immunoelectrophoresis, the trough was filled with an appropriate volume of antiserum after the electrophoretic separation of the proteins. Diffusion occurred over the next $48 \mathrm{~h}$ followed by saline washes, drying, and staining in the usual manner.

\section{Isopycnic sedimentation}

The sample was first prepared by $1: 5$ dilution in PBSEDTA and centrifugation at $192,000 \mathrm{~g}$ for $4 \mathrm{~h}$ at $20^{\circ} \mathrm{C}$ on a Spinco model $\mathrm{L}$ preparative ultracentrifuge with SW 50.1 rotor (Spinco Div., Beckman Instruments, Inc., Palo Alto, Calif.). The pellet was then dissolved in $0.2 \mathrm{ml}$ PBS-EDTA.

For gross banding, the prepared sample was delivered to a layered sucrose gradient of $60 \%-20 \%(\mathrm{wt} / \mathrm{vol})$ with successive layers each having a $10 \%$ concentration decrement. The solvents were either distilled water (plain sucrose solution) or PBS-EDTA (buffered sucrose solution). Centrifugation was carried out at $192,000 \mathrm{~g}$ for $15 \mathrm{~h}$ at $5^{\circ} \mathrm{C}$. Subsequently, $1.0 \mathrm{ml}$ fractions were withdrawn from the top of the tube and a final fraction prepared by suspending the pellet in $1.0 \mathrm{ml}$ of solvent. Each fraction was tested for $\mathrm{HB}$ $\mathrm{Ag}$ and serum proteins by double diffusion and for density by the method described below:

In order to make precise determinations of the buoyant density of $\mathrm{HB} \mathrm{Ag}$, a prepared sample was layered on a preformed linear gradient in PBS-EDTA of either sucrose or cesium chloride with a density range of $1.126-1.240 \mathrm{~g} / \mathrm{ml}$ or $1.120-1.400 \mathrm{~g} / \mathrm{ml}$, respectively. The subsequent handling was as above except that centrifugations were carried out for $24 \mathrm{~h}$ (serum $\mathrm{HB} \mathrm{Ag}$ ) or $48 \mathrm{~h}$ (purified $\mathrm{HB} \mathrm{Ag}$ ) and the fractions were collected from the bottom of the tube. Determinations of both $\mathrm{HB} \mathrm{Ag}$ and density were made on each fraction. In the case of purified $\mathrm{HB} \mathrm{Ag}$, the fractions were also monitored for absorbance at $280 \mathrm{~nm}$ with a Beckman DU spectrophotometer (Beckman Instruments, Inc.).

Determination of the sedimentation rate of $\mathrm{HB}$ Ag

Moving boundary method (15). Samples were run at three concentrations: undiluted and diluted $1: 5$ and $2: 5$ with PBS-EDTA. After centrifugation, $0.5 \mathrm{ml}$ samples were drawn from the top of the tube with individual syringes. Each fraction was tested for $\mathrm{HB} \mathrm{Ag}$ by the double diffusion technique. For each sample dilution, a sedimentation constant was calculated taking the boundary indicated by the uppermost fraction still having a $\mathrm{HB} \mathrm{Ag}$ positive test. The following formula was used.

$$
s t=\left[\frac{10^{13}}{4 \pi^{2}} \frac{1 n(r b / r)}{(\mathrm{rpm})^{2} \max }\right]\left[\frac{(\mathrm{rpm})^{2} \max }{(\mathrm{rpm})^{2}}\right]
$$

where $s$ is the observed sedimentation rate; $t$, time in hours; $r b$, the distance of the meniscus from the axis of rotation; $r$, the distance of the uppermost fraction containing $\mathrm{HB} \mathrm{Ag}$ from the axis of rotation at time, $t$.

Sedimentation rate of purified $\mathrm{HB} A g$ using the analytical ultraccutrifuge. Sedimentation runs were made on the Beckman Model $\mathrm{E}$ analytical ultracentrifuge with $\mathrm{AN}-\mathrm{D}$ rotor (Beckman Instrument, Inc.) at $24,000 \mathrm{rpm}$ using the standard cell at $20^{\circ} \mathrm{C}$ and schlieren optics.

Sedimentation constants were calculated for three different concentrations of purified $\mathrm{HB} \mathrm{Ag}$. The value at zero concentration was obtained by extrapolation and corrected to standard conditions (16).

\section{Diffusion coefficient}

Data for the diffusion coefficient were obtained with the synthetic boundary cell in the AN-D rotor run at $6,000 \mathrm{rpm}$ on the analytical ultracentrifuge at $20^{\circ} \mathrm{C}$. The diffusion coefficient was obtained by calculating variance of the curve and plotting on a probability chart, by the method of Markham (17).

\section{Density determination}

The density of a solution was obtained by weighing it in a tared $100 \mu 1$ pipet.

\section{Ether and sodium dodecyl sulfate treatment}

Purified $\mathrm{HB} \mathrm{Ag}$ or serum containing $\mathrm{HB} \mathrm{Ag}$ was mixed with an equal volume of ether and shaken for $2 \mathrm{~h}$ at $0^{\circ} \mathrm{C}$. Most ether was decanted off after a short centrifugation and the residual was evaporated by nitrogen gas.

A $10 \%$ stock solution of sodium dodecyl sulfate (SDS) was added to a $\mathrm{HB}$ Ag solution to make a final concentration of $1 \%$. This mixture was left at room temperature for $3 \mathrm{~h}$.

\section{Protein concentration}

Protein concentration was measured by the Lowry method (18) using freshly dissolved bovine serum albumin (BSA) as standard.

\section{Staining method}

Azocarmine $\mathrm{G}$ or amido schwarz $10 \mathrm{~B}$ was used to stain protein (19) ; sudan black B, lipid (19); and periodic acid fuchsin sulfite (PAS), carbohydrate (20).

\section{Electron microscopy}

Samples for electron microscopy were prepared in $0.1 \%$ ammonium acetate buffer at $\mathrm{pH} 6.4$ containing $0.05 \% \mathrm{BSA}$ (ammonium acetate-BSA buffer). Before staining, a sample was mixed with an equal volume of a dilution of latex particles. 


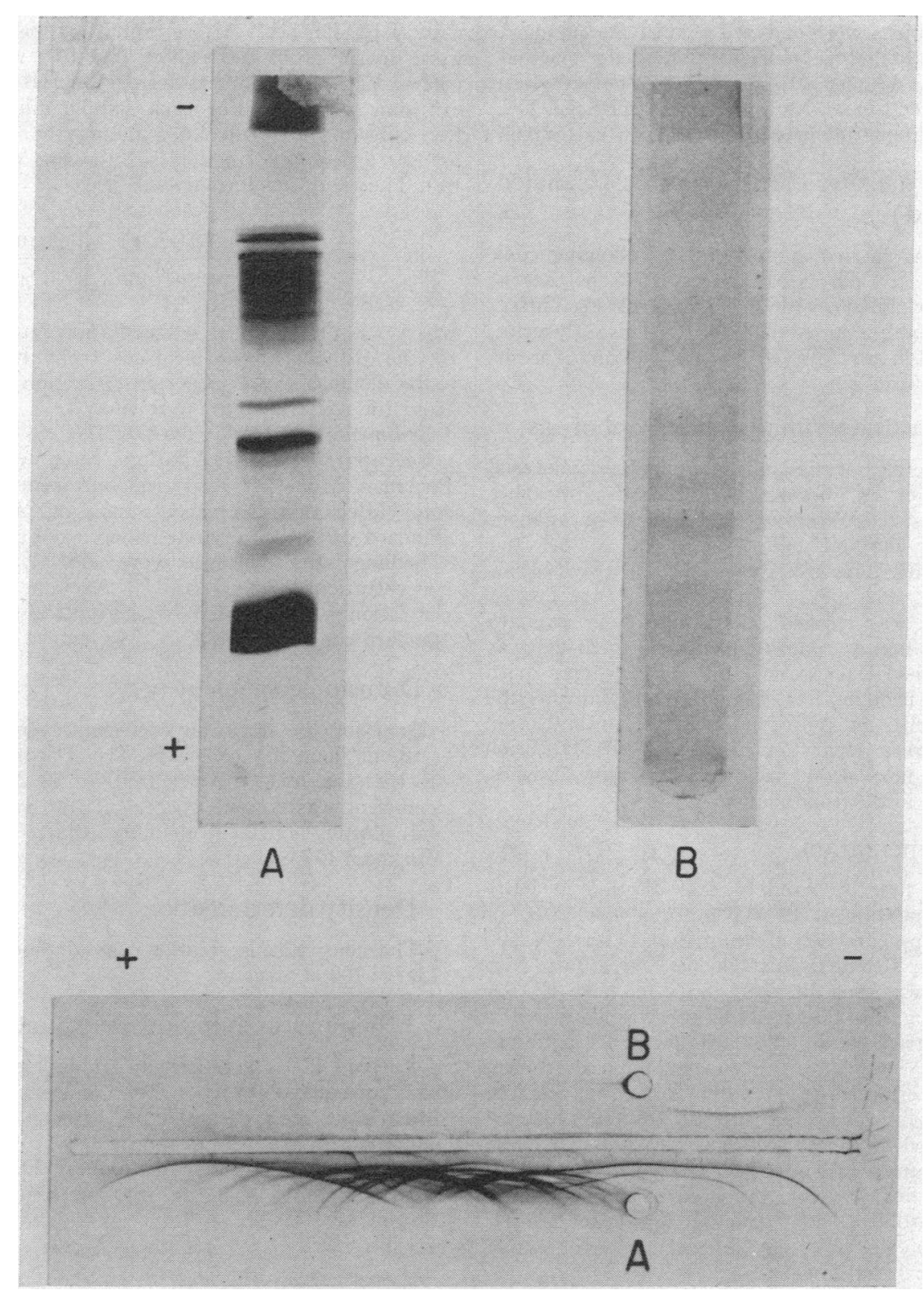

FIGURE 1 Effect of pepsin digestion on serum protein. Disc gel electrophoresis (above) was performed as described in Methods with a $10 \mu \mathrm{l}$ sample which had been prepared from serum by dilution either in a buffer solution $(A)$ or pepsin solution $(B)$ and incubated for $180 \mathrm{~min}$. Agarose immunoelectrophoresis (below) was carried out as described in Methods and developed by using horse antiserum against whole normal human serum, $70 \mu 1$.

The latter had a mean diameter of $880 \pm 80 \AA$ and concentration of $2.7 \times 10^{14}$ particles per milliliter (Particle Information Service, Los Angeles, Calif.). Negative stains were made with fresh solutions of $0.1 \%$ ammonium acetate containing $1 \%$ uranyl acetate and $0.35 \%$ EDTA with a final $\mathrm{pH}$ of 6.4 . When dry, the negative stains were examined with a Phillips EM-200 electron microscope (Phil- lips Electronic Instruments, Mount Vernon, N. Y.) at film magnifications from 56,600 to 159,000 .

The concentration of test particles in a sample was calculated by multiplying the ratio of the number of test to control particles found by electron microscopy by the initial concentration of control particles. Test particle diameters were obtained by comparison of their projected images with 
that of the control particles whose real diameter was known (21).

\section{RESULTS}

Characterization of serum $\mathrm{Hb} \mathrm{Ag}$ with and without pepsin digestion

Effect of pepsin digestion on serum protein and $H B$ Ag immunoreactivity. There was a profound reduction in serum protein after digestion with pepsin. This is documented by the polyacrylamide gel disc electrophoresis of $\mathrm{HB} \mathrm{Ag}$ positive serum with and without digestion by pepsin shown in Fig. 1. Also shown in Fig. 1 are the results of immunoelectrophoresis, in which the $\mathrm{HB}$ Ag positive serum with or without pepsin digestion was first subjected to ordinary gel electrophoresis and then diffused against horse antiserum to whole normal human serum. It can be seen that, although native $\mathrm{HB}$ Ag positive serum gave precipitin lines typical for normal serum, the pepsin digestion sample had an immunoelectrophoreogram almost devoid of precipitin lines. Similar results were found with the double diffusion reaction using multi-valent horse antiserum against whole normal human serum (Hyland Laboratory, Costa Mesa, Calif., not shown). However, of particular importance is the fact that with the modified double diffusion test (14) it was found that pepsin digestion did not diminish the titer of HB Ag.

Sedimentation rate of serum $\mathrm{HB} \mathrm{Ag}$. The sedimentation rate of serum $\mathrm{HB} \mathrm{Ag}$ at $20^{\circ} \mathrm{C}$ was determined by the moving boundary method, as described in Methods. It is seen in Fig. 2 that the observed sedimentation rate extrapolated to zero concentration was just under

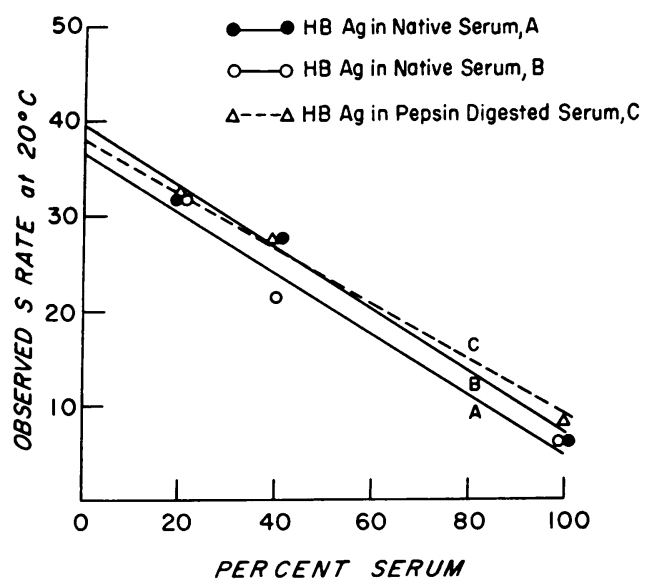

FIGURE 2 Sedimentation rate of $\mathrm{HB} \mathrm{Ag}$ in serum. Two samples of native serum $\mathrm{HB} \mathrm{Ag}, A$ and $B$, and one sample of pepsin digested serum $\mathrm{Hb} \mathrm{Ag}, C$, were centrifuged undiluted as well as diluted to $1: 5$ and $2: 5$ in PBS-EDTA. The observed sedimentation rates at $20^{\circ} \mathrm{C}$ were calculated by the moving boundary method as described under Methods.

40 at $20^{\circ} \mathrm{C}$ both for $\mathrm{HB} \mathrm{Ag}$ in the native serum samples and for $\mathrm{HB} \mathrm{Ag}$ in the serum treated by pepsin.

Isopycnic sedimentation. Banding of serum $\mathrm{HB} \mathrm{Ag}$ and protein. Samples containing HB Ag were banded by equilibrium sedimentation in sucrose gradients of $20 \%-60 \%(\mathrm{wt} / \mathrm{vol})$ in distilled $\mathrm{HOH}$ as described in Methods.

As shown in Fig. 3, if the sample had not been pepsin digested, serum proteins were found in all fractions and $\mathrm{HB} \mathrm{Ag}$ was found both in fraction 4 and the pellet

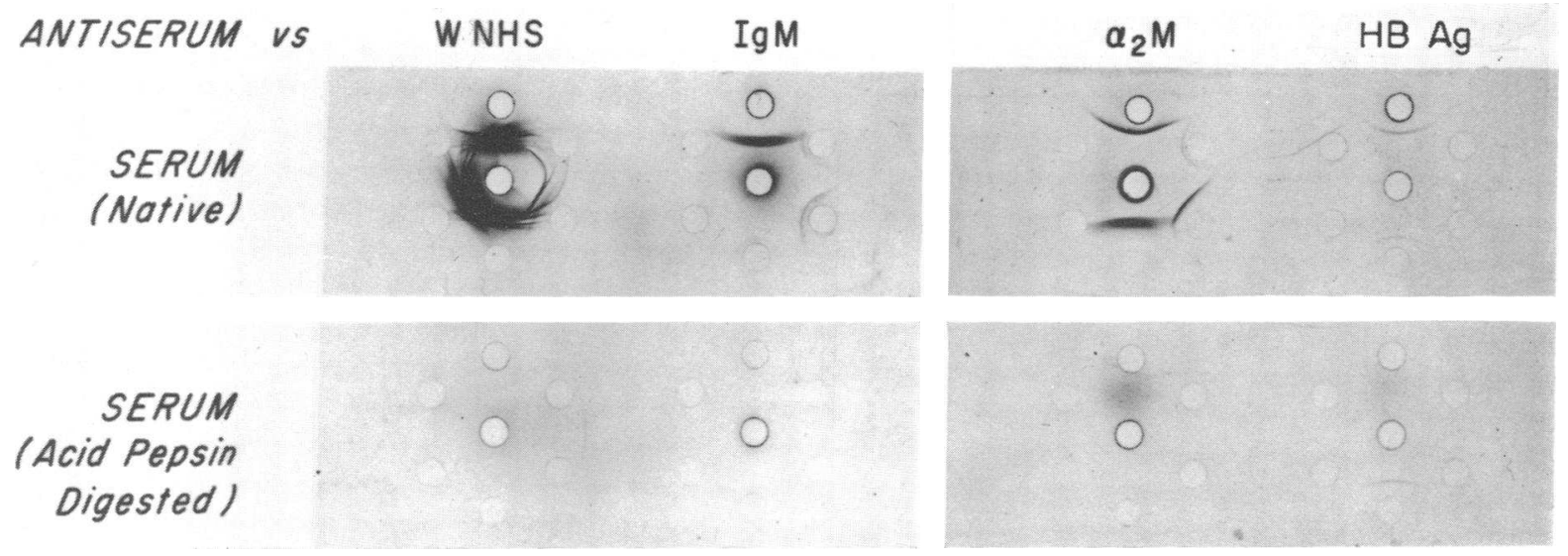

FIGLRE 3 Distribution of $\mathrm{HB} \mathrm{Ag}$ and serum proteins after sucrose gradient sedimentation. Serum containing HB Ag was prepared, applied to a layered sucrose density gradient (20$60 \%$ ) in distilled water, and sedimented at $192,000 \mathrm{~g}$ for $15 \mathrm{~h}$ as described in Methods. 1.0 $\mathrm{ml}$ fractions were collected from above and tested by the modified double diffusion technique for $\mathrm{HB} \mathrm{Ag}$, normal serum proteins (WNHS), Ig $\mathrm{M}$ and $\alpha_{2}$-macroglobulin by using the appropriate antisera in the center well. The gradient fractions were placed in the peripheral wells in a clock-wise fashion beginning with the pellet fraction at 12 o'clock. 


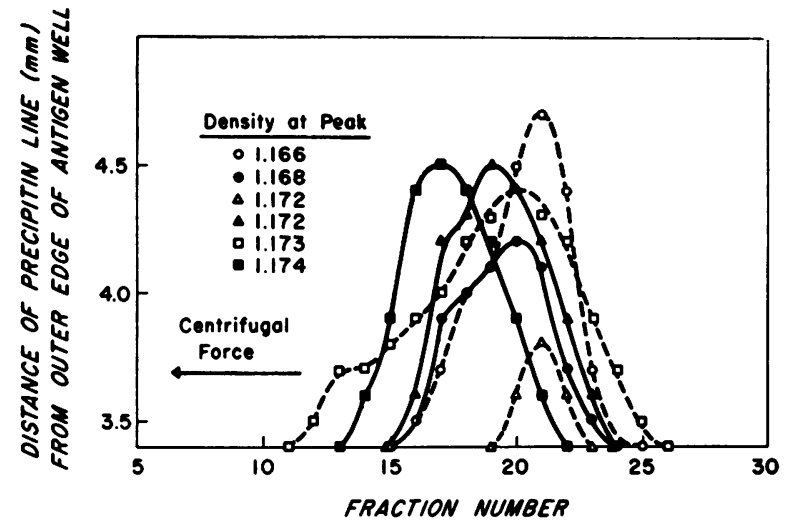

FIgURE 4 Buoyant density distribution of serum $\mathrm{HB} \mathrm{Ag}$ insucrose. Prepared serum samples were sedimented on a linear sucrose density gradient for $24 \mathrm{~h}$ as described in Methods. Fractions were collected dropwise from below and tested for $\mathrm{HB} \mathrm{Ag}$ and density.

(12:00 o'clock). However, when the sample had first been digested with acid-pepsin for at least $2 \mathrm{~h}$ and then subjected to equilibrium sedimentation, human serum proteins were no longer found in any fraction. Furthermore, although $\mathrm{HB} \mathrm{Ag}$ was not found in the pellet, it was still present in fraction 4.

Buoyant density of serum HB Ag. The precise buoyant density distribution of serum $\mathrm{HB} \mathrm{Ag}$ was determined in linear sucrose gradients as described in Methods. It was found to be variable, with the modal density for serum $\mathrm{HB} \mathrm{Ag}$ from six patients ranging from 1.166 to $1.174 \mathrm{~g} / \mathrm{ml}$ (Fig. 4). Identical buoyant density was observed for samples treated with either pepsin or ether (not shown).

Shape and size of particles found in gradient fractions containing $\mathrm{HB} \mathrm{Ag}$. After banding by isopycnic sedi-

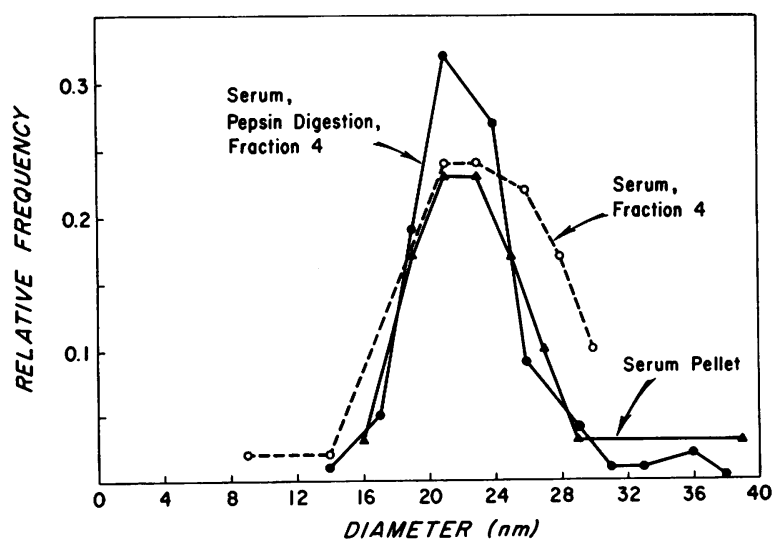

Figure 5 Particle diameter. From the sucrose density gradients depicted in Fig. 3 , the pellet fraction and fraction 4 of native serum, and fraction 4 of the sample first digested with pepsin, were prepared for electronmicroscopy and the particles sized as described in Methods.

1180

$$
\text { C. Y. Kim and J. G. Tilles }
$$

mentation on a plain sucrose gradient, the pellet fraction and fraction 4 of native $\mathrm{HB} \mathrm{Ag}$ and fraction 4 of a pepsin digested sample of the same serum were each dialyzed against PBS-EDTA for $24 \mathrm{~h}$, concentrated, and prepared for electron microscopic examination as described in Methods.

The distribution of particle diameters observed in each of the fractions is shown in Fig. 5.

The modal particle diameter is seen to be $22 \mathrm{~nm}$ for both fraction 4 and the pellet fractions from native serum. While the latter has a symmetrical distribution the former is skewed with a sizable proportion of particles having a diameter greater than the mode. Fraction 4 of the pepsin digested serum does have a symmetrical distribution of particle diameters. Although the modal diameter is similar to that for the other fractions, there is even less variation.

The shape of the particle was almost invariably circular, indicating spherical forms. An elongated particle indicating a tubular form, with the small diameter equal to the modal diameter of the other particles, could occasionally be seen. Under the conditions used, the long diameter seldom reached a length twice the smaller.

There was no apparent difference in shape among the particles found in the three fractions.

\section{Purification and concentration of $\mathrm{Hb} \mathrm{Ag}$}

It is evident from the above data that pepsin digestion of $\mathrm{HB} \mathrm{Ag}$ positive serum followed by sucrose gradient isopycnic sedimentation gives a sucrose fraction that retains $\mathrm{HB} \mathrm{Ag}$ but has no detectable serum protein. To provide material for further characterization of the

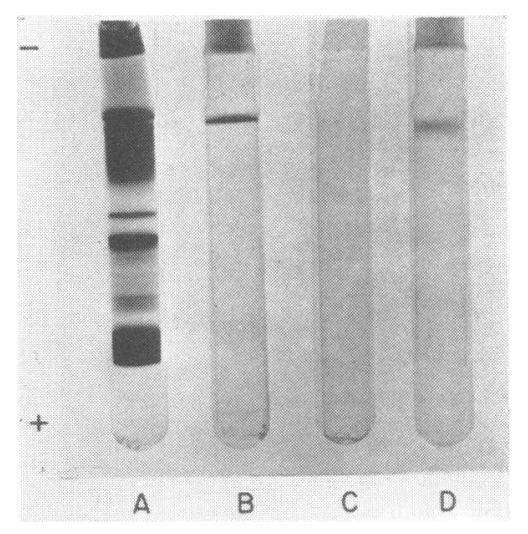

Figure 6 Polyacrylamide gel electrophoresis of purified HB Ag. The disk gel electrophoresis was carried out under the conditions noted in Methods on the following samples: $A$, an $\mathrm{HB} \mathrm{Ag}$ positive serum; $B$ and $D$, purified $\mathrm{Hb} \mathrm{Ag}$; and $C$, a control prepared from an $\mathrm{HB} \mathrm{Ag}$ negative serum subjected to the purification process. Sample $D$ was run on $4 \%$ gel and the others, on $7 \%$ gel. 
purified product, batches of plasma or serum were subjected to the above treatments, pooled, dialysed against buffer, and clarified by low speed centrifugation. HB Ag was concentrated by pelleting and resuspending in PBSEDTA.

The final solution was subjected to a second isopycnic sedimentation using identical technique but this time in a linear cesium chloride gradient in PBS-EDTA.

Fractions from the HB Ag peak were pooled, dialysed against $\mathrm{PBS}-\mathrm{EDTA}$, concentrated by ultracentrifugation, and dissolved in a suitable volume of PBS-EDTA to give again a calculated concentration of 200 -fold over the serum sample. The observed concentration of $\mathrm{HB} \mathrm{Ag}$ by the modified double diffusion test (14) was also 200 -fold, indicating minimal if any loss.

\section{Properties of purified $\mathrm{Hb} \mathrm{Ag}$}

Polyacrylamide gel disc electrophoresis. HB Ag preparations purified by the aforementioned method were subjected to disc gel electrophoresis to test homogeneity (Fig. 6).

In the $7 \%$ acrylamide gel the purified $\mathrm{HB}$ Ag sample revealed a homogeneous band which migrated to the portion of the separating gel immediately adjacent to the stacking gel. The purified $\mathrm{HB} \mathrm{Ag}$ band migrated further into the separating gel when the sample was electrophoresed on a $4 \%$ gel. Thus, the protein appeared to be of high molecular weight and there was no evidence of contaminating serum proteins.

Buoyant density. The distributions of buoyant density for a $0.1 \mathrm{ml}$ sample of purified $\mathrm{HB} \mathrm{Ag}$ are seen in Fig. 7. The distribution peaks on sucrose and cesium chloride occur at densities of 1.170 and $1.216 \mathrm{~g} / \mathrm{ml}$, respectively.

Sedimentation coefficient. Analytical ultracentrifugation of purified $\mathrm{HB} \mathrm{Ag}$ revealed a single sedimenting peak (Fig. 8). As described in Methods, observed values of the sedimentation constant have been determined at three different concentrations of $\mathrm{HB}$ Ag. The sedimentation coefficient has been calculated from the sedimentation constant extrapolated to zero concentration and corrected to standard conditions (water at $\left.20^{\circ} \mathrm{C}\right)$. The value is $40.2\left(\mathrm{~S}^{\circ}{ }_{20, \mathrm{~m}}\right)$.

Diffusion coefficient. The diffusion coefficient of purified $\mathrm{HB} \mathrm{Ag}$ at $20^{\circ} \mathrm{C}$, was obtained by analytical ultracentrifugation as described in Methods and found to be $2.278 \times 10^{-7} \mathrm{~cm}^{2} \mathrm{~s}^{-1}$.

Molecular weight. The molecular weight of $\mathrm{HB} \mathrm{Ag}$ was calculated from the Svedberg equation $(16,17)$ using the above values for $s$ and diffusion coefficient. The molecular weight was found to be $2.4 \times 10^{\circ}$.

Staining characteristics. Drops of a purified $\mathrm{HB}$ Ag preparation with a concentration of $1.0 \mathrm{mg} / \mathrm{ml}$ (as $\mathrm{HB}$ $\mathrm{Ag}$ protein) were allowed to dry on a microscope slide.

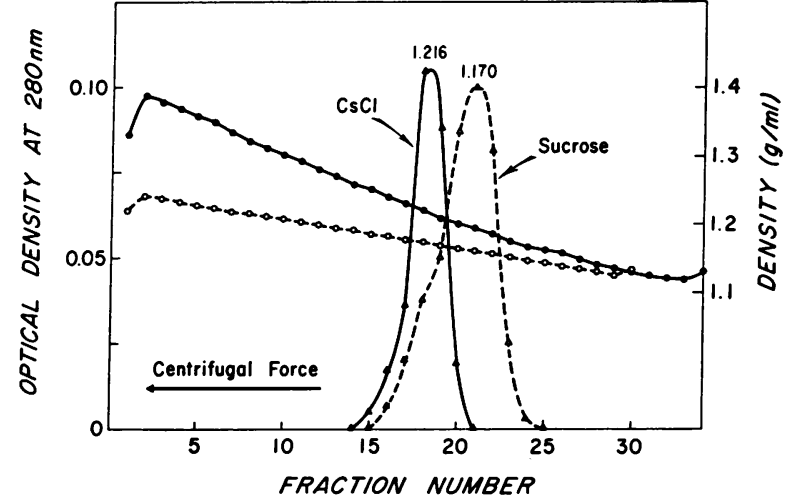

FIGURE 7 Buoyant density of purified HB Ag. $100 \mu \mathrm{l}$ of purified $\mathrm{HB} \mathrm{Ag}, 1.0 \mathrm{mg}$ protein per milliliter, was layered on the top of a performed linear gradient of sucrose or cesium chloride in PBS-EDTA and sedimented for $48 \mathrm{~h}$ as described in Methods. Determinations were made of density, circles, and optical density (OD), triangles, on fractions collected dropwise from below. The solid and open symbols refer to cesium chloride and sucrose, respectively.

Staining was carried out for protein, lipid, and carbohydrate as described in Methods.

HB Ag stained readily with protein and lipid dyes and to a more limited degree with PAS stain.

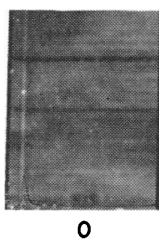

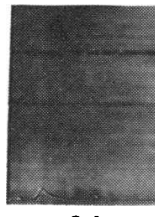

24

MINUTES

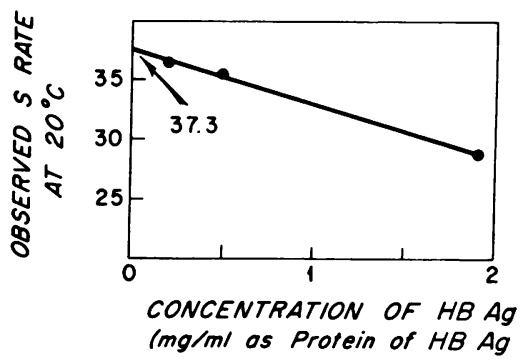

Calculated S20,w : 40.2
Figure 8 Sedimentation of purified HB Ag. Above, a sedimentation sequence of purified $\mathrm{HB} \mathrm{Ag}, 1.9 \mathrm{mg} \mathrm{HB} \mathrm{Ag}$ protein per milliliter, in PBS-EDTA is traced with the Beckman model $\mathrm{E}$ analytical ultracentrifuge. Below, the observed sedimentation constants are plotted for three concentrations of purified HB Ag. The sedimentation coefficient was calculated for standard conditions using the observed rate extrapolated to zero concentration. 


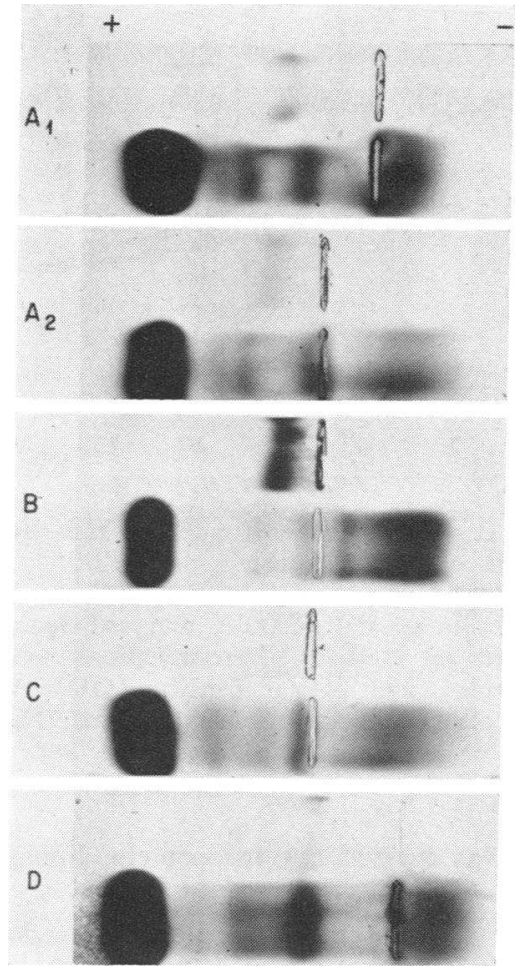

Figure 9 Electrophoresis of purined $\mathrm{HB}$ Ag. $\mathrm{HB} \mathrm{Ag}$ was purified from the serum of each of four individuals. For each slide the upper half received $5 \mu 1$ of purified HB $\mathrm{Ag}$ and the lower half received a similar volume of the original serum. The supporting medium for $A_{1}$ and $D$ was agarose and for the others, agar. $\mathrm{HB} \mathrm{Ag}$ from samples $A$, $B$, and $C$ migrates in the inter $\alpha_{2}-\beta$ region and from sample $D$, in the $\beta$ region.

Although an ether treated preparation of purified HB Ag retained its ability to stain well with sudan black $\mathrm{B}, \mathrm{HB} \mathrm{Ag}$ preparations treated by a chloroform-methanol mixture (2:1, 20 vol for $20 \mathrm{~min}$ ), stained poorly with the same reagent. Thus some lipid that could be removed by the chloroform-methanol mixture could not be removed by ether.
Electrophoretic mobility. Purified HB Ag from most individuals migrated as a homogeneous band in the inter $\alpha_{2}-\beta$ globulin region when compared to serum proteins on either agar or agarose gel electrophoresis (Fig. $9 A, B$, and $C$ ). $\mathrm{HB} \mathrm{Ag}$ from other individuals moved primarily with $\beta$-globulin mobility but trailed into the inter $\alpha_{2}-\beta$ region (Fig. $9 D$ ). On immunoelectrophoresis the mobility before and after purification was found to be identical (Fig. 10). Serum $\mathrm{HB} \mathrm{Ag}$ from a given individual always behaved in the same manner.

Electron microscopy of purified $\mathrm{HB} A g$. Purified HB Ag was diluted 1:100 with ammonium acetateBSA buffer because the particle concentration at lower dilution was too dense for resolution. By comparison with control particles as described in Methods, the initial concentration of $\mathrm{HB} \mathrm{Ag}$ particles in the purified preparation was calculated to be $6.7 \times 10^{15} / \mathrm{ml}$ (Fig. $11 \mathrm{a}$ ). As already described, the size of $\mathrm{HB} \mathrm{Ag}$ was variable, ranging from $14 \mathrm{~nm}$ to $38 \mathrm{~nm}$ in diameter, but the spherical structure with fine granular surface was invariably found (Fig. $11 b$ ). When the HB Ag preparation was mixed with specific antiserum there was gross agglutination immediately. Control preparations including that used in Fig. $6 c$ showed no particles.

When an $\mathrm{HB} \mathrm{Ag}$ preparation was treated with either ether or SDS, the gross structure of $\mathrm{HB} A g$ was not changed but the particles clumped.

\section{DISCUSSION}

Digestion with proteolytic enzymes and nucleases was first used in the purification of animal viruses in the 1950 's $(22,23)$. We initially considered enzyme digestion to remove persistent serum contaminants from $\mathrm{HB} \mathrm{Ag}$ because of accumulating circumstantial evidence of the relationship of $\mathrm{HB} \mathrm{Ag}$ to an agent of hepatitis. Assuming oral infection with the agent under some circumstances, we hypothesized that on such occasions infectivity must resist proteolytic enzyme digestion in the gastrointestinal tract. In fact, $\mathrm{HB} \mathrm{Ag}$ immunoreactivity has been found to be stable to most of the proteolytic en-

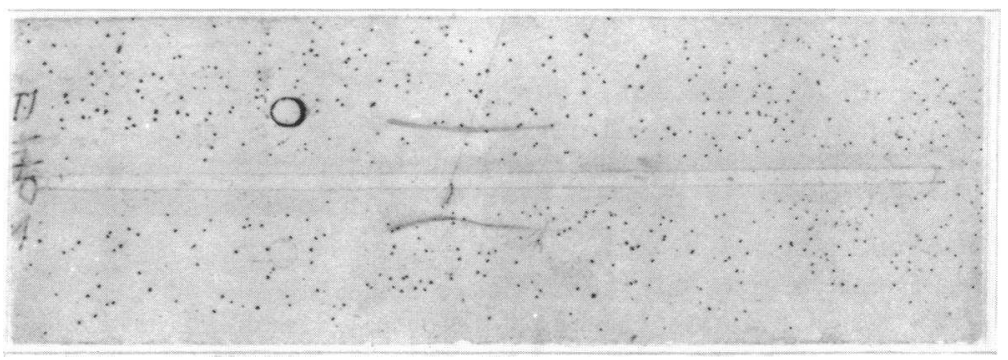

FIgURE 10 Immunoelectrophoresis of $\mathrm{HB}$ Ag. Serum containing $\mathrm{HB} \mathrm{Ag}, 5 \mu 1$, was applied to the lower well and HB Ag purified from that serum, to the upper well. After electrophoresis, the trough was filled with $\mathrm{HB} A g$ antiserum $(100 \mu 1)$, from rabbits immunized with purified $\mathrm{HB} \mathrm{Ag}$. The precipitin lines have been darkened for reproduction. 

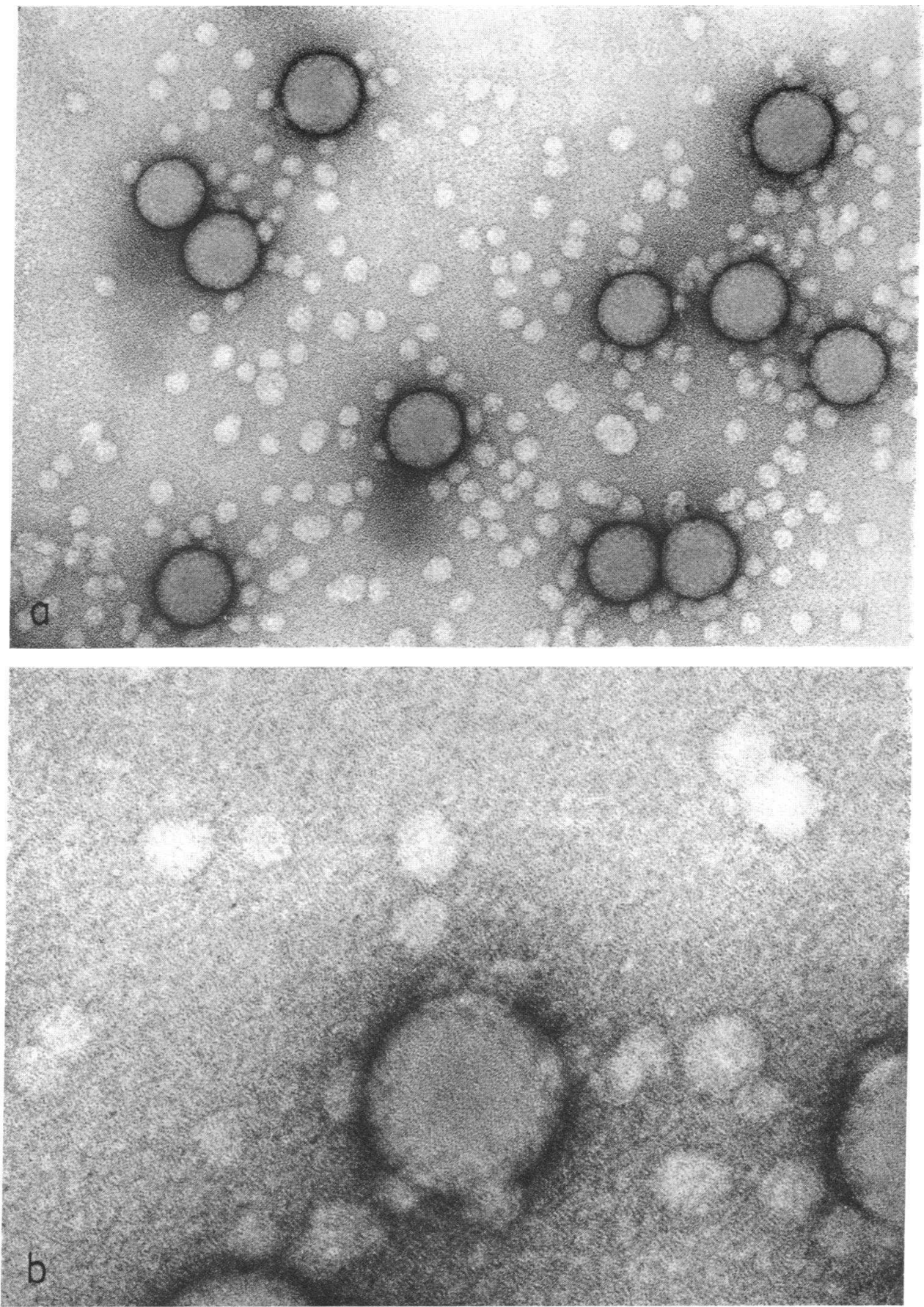

FIGURE 11 Ultrastructure of purified HB Ag. Negative stain with uranyl acetate of purified $\mathrm{HB} \mathrm{Ag}(a$ and $b)$. Larger particles are lucite reference particles with mean diameter of $880 \AA$.

zymes tested (24). Millman, Loeb, Bayer, and Blumberg (25) have attempted to purify $\mathrm{HB} \mathrm{Ag}$ using a series of proteolytic enzymes not including pepsin.

In the present report pepsin digestion and equilibrium sedimentation on a sucrose density gradient yielded pure
HB Ag in most cases. However, subsequent fractionation by ultracentrifugation in a linear cesium chloride gradient was found necesary to eliminate a contaminant demonstrated in some preparations. This material was located near the bottom of the cesium chloride gradient 
TABLE I

Biophysical Properties of $H B$ Ag (Solvent: PBS-EDTA, $p H$ 7.8)

$\begin{array}{ll}\mathrm{S}^{\circ}{ }_{20, \mathrm{w}} & 40.2 \\ \text { Density } & 1.170 \text { in sucrose } \\ & 1.216 \text { in cesium chloride } \\ \text { Particle size } & 22 \mathrm{~nm}(\text { range } 14-38 \mathrm{~nm}) \\ \text { Concentration } & 6.7 \times 10^{15} \mathrm{particles} / \mathrm{ml} \\ \text { Diffusion coefficient }\left(\text { at } 20^{\circ} \mathrm{C}\right) & 2.278 \times 10^{-7} \mathrm{~cm}^{2} \mathrm{~s}^{-1} \\ \text { Molecular weight } & 2.4 \times 10^{6} \\ \text { Electrophoretic mobility } & \beta \text { or inter } \alpha_{2}-\beta \text { globulin }\end{array}$

(density about $1.40 \mathrm{~g} / \mathrm{ml}$ ) and was degradable by DNase.

Before considering the values reported for the physical properties of purified $\mathrm{HB} \mathrm{Ag}$, two questions should be answered: What evidence is there that the particle studied was homogeneous? And, was the particle unchanged by the purification procedure? The evidence that the purified particle was homogeneous will be taken up first.

Purified HB Ag displayed a single sedimenting peak on analytical ultracentrifugation. In addition the $\mathrm{HB} \mathrm{Ag}$ preparation exhibited a single band on polyacrylamide gel disk electrophoresis with no evidence of any serum protein contaminant. Further evidence of the absence of serum protein was the absence of a precipitin line when diffused against either horse or rabibt antiserum to whole normal human serum. Moreover, immunization of rabbits and guinea pigs with purified HB Ag produced monovalent antisera which yielded a reaction of identity when diffused against $\mathrm{HB} \mathrm{Ag}$ in serum and purified $\mathrm{HB} \mathrm{Ag}$ on Ouchterlony plates (26).

Evidence that the particle underwent no physical change during the purification procedure is provided by the failure of pepsin digestion to alter the density, ultrastructure, sedimentation rate, or electrophoretic mobility of $\mathrm{HB} \mathrm{Ag}$. The concentration of $\mathrm{HB} \mathrm{Ag}$ determined by the modified immunodiffusion method $(13,14)$ before and after pepsin digestion proved to be undiminished. Immunological evidence of the stability of $\mathrm{HB}$ Ag during purification was the finding of a reaction of identity when $\mathrm{HB} \mathrm{Ag}$ from before and after purifica- tion was diffused against $\mathrm{HB} \mathrm{Ag}$ antiserum. Thus, the purified $\mathrm{HB} \mathrm{Ag}$ reported here is homogeneous and similar to native $\mathrm{HB} \mathrm{Ag}$ physically and immunologically.

The biophysical properties of $\mathrm{HB} \mathrm{Ag}$ are summarized in Table I. The $\mathrm{S}^{\circ}{ }_{20, \mathrm{w}}$ of 40.2 for purified $\mathrm{HB} \mathrm{Ag}$ obtained in the analytical ultracentrifuge compares favorably with the estimate of just under 40 derived for HB $\mathrm{Ag}$ in serum by the moving boundary technique. For partially purified HB Ag, Gerin, Purcell, Hoggan, Holland, and Chanock (7) have reported a value for $S^{\circ}{ }_{20, w}$ of 110 obtained by rate zonal separation on a sucrose density gradient. The difference from the present data may be explained by aggregation of the $\mathrm{HB} \mathrm{Ag}$ which the latter demonstrated by electron microscopy. Furthermore, the reference virus used undoubtedly had a density significantly different from HB Ag. In a subsequent report (12), the same authors have estimated the $\mathrm{S}^{\circ}{ }_{20, \mathrm{w}}$ to be 54 .

The density of purified HB Ag is compared to the densities found by others in Table II.

It has already been shown that partially purified $\mathrm{HB}$ Ag particles are pleomorphic, with most particles spheroidal and a variable number tubular $(3,9)$. Under the conditions of the present work, the purified $\mathrm{HB}$ Ag particles were also found to be predominantly spheroidal. The modal diameter of the purified particle is compared to the estimates of modal diameter made by others in Table III.

The diffusion coefficient given for purified $\mathrm{HB} \mathrm{Ag}$ is the only known estimate of that parameter.

The molecular weight of purified $\mathrm{HB} \mathrm{Ag}$ was found to be $2.4 \times 10^{\circ}$, as calculated by the Svedberg equation. Alter and Blumberg (11) predicated a high molecular weight for $\mathrm{HB} A g$ when they found that $\mathrm{HB} \mathrm{Ag}$ appeared along with serum macroglobulins in the first peak from a Sephadex G-200 column.

When purified HB Ag was derived from the serum of individual patients, it was found to have one of two types of electrophoretic mobility. It either migrated in the inter $\alpha_{2}-\beta$-globulin region or in the $\beta$-globulin region with a trail into the former region. We have already reported that these two mobilities are found for $\mathrm{HB} \mathrm{Ag}$

TABLE II

Comparison of HB Ag Densities Reported

\begin{tabular}{|c|c|c|c|}
\hline \multirow[b]{2}{*}{ Gradient } & \multirow[b]{2}{*}{ Sucrose } & Density & \multirow[b]{2}{*}{ Potassium Tartrate } \\
\hline & & Cesium Chloride & \\
\hline \multicolumn{4}{|c|}{$g / m l$} \\
\hline Present report & 1.170 & 1.216 & \\
\hline Alter and Blumberg (11) & $1.063-1.30$ & & \\
\hline Gerin et al. (7) & 1.16 & 1.20 & 1.15 \\
\hline Barker et al. (6) & & $1.22-1.27$ & \\
\hline
\end{tabular}


in native serum and correlate with differences in immunologic reactivity (27), i.e., antigen with $\beta$-mobility always carries the $c$ antigenic determinent ( $d$ of LeBouvier [28]) and antigen with the $c$ determinant always has $\beta$-mobility. Alter and Blumberg (11) have noted that on immunoelectrophoresis of partially purified $\mathrm{HB} \mathrm{Ag}$ an arc extended all the way from the antigen well to the $\alpha_{1-g}$ globulin region and thus completely encompassed the area where purified $\mathrm{HB}$ Ag migrates.

It is not known if the immunological subtypes of $\mathrm{HB}$ Ag differ in physical properties other than electrophoretic mobility. And such differences are probably small since the values found here for the properties of $\mathrm{HB} \mathrm{Ag}$ purified from a pool of sera, (later found to contain both subtypes) have a normal distribution and are identical to those which can be measured for native $\mathrm{HB} \mathrm{Ag}$ in inclividual sera.

It has been previously suggested on the basis of the staining characteristics of the precipitin lines produced by $\mathrm{HB} \mathrm{Ag}$ positive sera that the particle might contain lipid (11). In the present work, purified $\mathrm{HB} \mathrm{Ag}$ stained with protein and lipid dyes, and PAS stain as well which suggested that $\mathrm{HB} \mathrm{Ag}$ also contains carbohydrate.

There have been reports that $\mathrm{HB} \mathrm{Ag}$ became denser after treatment with ether or detergent, which led researchers to postulate a causal connection between lipid extraction and their findings $(6,7)$. We could not find any change in the density of $\mathrm{HB} \mathrm{Ag}$ after ether treatment under the conditions described. In fact, polar lipid chromatogram of purified $\mathrm{HB} \mathrm{Ag}$ has revealed that ether treatment alone does not cause the delipidation of the phospholipids of HB Ag (24). Since the particles tended to aggregate after ether or SDS treatment, it is tempting to suggest that the increased density after ether or detergent treatment found by others may have been due to such aggregation.

Hepatitis B antigen may be a particle of extremely small size and light density (due to the lipid it contains) derived from the sick liver of the hepatitis patient; it might be an incomplete virus particle; or it might be the virus itself. Because the level of antigenemia is sometimes falling when the earliest chemical signs of hepatitis are detected and since severe hepatitis of other causes is not associated with $\mathrm{HB} \mathrm{Ag}$, it is doubtful that $\mathrm{HB} \mathrm{Ag}$ represents a liver breakdown product.

The likelihood that the particle is mature virus can be estimated from the biophysical characteristics given. It is evident that both the values for sedimentation coefficient and molecular weight are much smaller than those for any known virus. Furthermore, although viruses with a density as low as that of $\mathrm{HB} \mathrm{Ag}$ do occur, they are always larger. Viruses the size of $\mathrm{HB} \mathrm{Ag}$ have a higher density because of the greater relative contribution of nucleic acid in particles of that size. Thus the
TABLE III

Reported Diameters for $H B$ Ag Particles

\begin{tabular}{lll}
\hline & \multicolumn{1}{c}{ Sample } & \multicolumn{1}{c}{ Modal size } \\
\hline & & \multicolumn{1}{c}{.$\dot{ }$} \\
Present & Pure & 220 \\
Bayer et al. (3) & Partially purified & $190-210$ \\
Gerin et al. (7) & Partially puritied & 250 \\
Gerin et al. (12) & Pure & 220 \\
Barker et al. (6) & Partially purified & 200 \\
Almeida and Waterson (9) & Pelleted serum & 200 \\
Dane et al. (10) & Pelleted serum & 220 \\
\hline
\end{tabular}

particles that have been purified and characterized in the present report are probably not virus. It is much more likely that they are incomplete virus which would also explain why we have only been able to find about $1 \%$ nucleic acid in these particles. However, since serum containing $\mathrm{HB} \mathrm{Ag}$ is highly infectious, it necessarily must contain many infectious units. We have found $10^{13}$ $\mathrm{HB} \mathrm{Ag}$ particles per milliliter of blood. Therefore, even at a ratio as low as 1 infectious particle per $10^{\circ}$ noninfectious particles there would still be $10^{\circ}$ infectious particles per milliliter of blood which is adequate to explain every known estimate of infectivity. Of course, the physical and chemical characterization of the preparation would be that of the vast majority of particles which, in fact, might be incomplete virus.

Dane (10) was the first to identify in sera containing $\mathrm{HB} \mathrm{Ag}$ the occasional occurrence of particles having a diameter about two times that of $\mathrm{HB} \mathrm{Ag}$. It is entirely possible that these larger particles are the complete virus and make up the infectious unit.

\section{ACKNOWLEDGMENTS}

The authors express their deep appreciation to Doctors Charles S. Davidson and Maxwell Finland for making this work possible. They also wish to thank Michael Gutwein for his technical assistance.

This investigation was supported, in part, by a contract between Harvard University and the Research and Development Command, Office of the Surgeon General, Department of the Army, by Public Health Service Grants nos. AM-09115, AM-05413, and FR-0076, 5RO1-A1-01695, and 2T01-A1-00068 from the National Institutes of Health, Bethesda, Maryland, and Grant 05-041-012 from the National Aeronautics and Space Administration.

\section{REFERENCES}

1. Blumberg, B. S., H. J. Alter, and S. Visnich. 1965. A new antigen in leukemic sera. J. Am. Med. Assoc. 191: 541.

2. Blumberg, B. S., B. J. S. Gerstley, D. A. Hungerford, W. T. London, and A. I. Sutnick, 1967. Serum antigen (Australia antigen) in Down's syndrome, leukemia and hepatitis. Ann. Intern. Med. 66: 924. 
3. Bayer, M. E., B. S. Blumberg, and B. Werner. 1968. Particles associated with Australia antigen in the sera of patients with Leukemia, Down's syndrome and hepatitis. Nature (Lond.). 218: 1057.

4. Prince, A. M. 1968. An antigen detected in the blood during the incubation period of serum hepatitis. Proc. Natl. Acad. Sci. U. S. A. 60: 814.

5. Hirschman, R. J., N. E. Shulman, L. F. Barker, and K. O. Smith. 1969. Virus-like particles in sera of patients with infectious and serum hepatitis. J. Am. Med. Assoc. 208: 1667

6. Barker, L. F., K. O. Smith, W. D. Gehle, and N. R. Shulman. 1969. Some antigenic and physical properties of virus-like particles in sera of hepatitis patients. $J$. Immunol. 102: 1529 .

7. Gerin, J. L., R. H. Purcell, M. D. Hoggan, P. V. Holland, and R. M. Chanock. 1969. Biophysical properties of Australia antigen. J. Virol. 4: 763.

8. Kater, R. M. H., C. Y. Kim, and C. S. Davidson. 1969. Australia antigen and viral hepatitis. J. Infect. Dis. 120: 391.

9. Almeida, J. D., and A. P. Waterson. 1969. Immune complexes in hepatitis. Lancet. $2: 983$.

10. Dane, D. S., C. H. Cameron, and M. Briggs. 1970 Virus-like particles in serum of patients with Australia antigen associated hepatitis. Lancet. 1: 695.

11. Alter, H. J., and B. S. Blumberg. 1966. Further studies on a new human isoprecipitin system (Australia antigen). Blood J. Hematol. $27: 297$.

12. Gerin, J. L., P. V. Holland, and R. H. Purcell. 1971. Australia antigen: large scale purification from human serum and biochemical studies of its proteins. J. Virol. $7: 569$.

13. Kim, C. Y. 1970. An immunochemical method for serum $\alpha$-globulin quantitative determination by micro-Ouchterlony double diffusion. Lab. Invest. 23: 79.

14. Kim, C. Y., and J. G. Tilles. 1971. Quantitation of hepatitis associated antigen with a modified Ouchterlony precipitin test. J. Infect. Dis. 124: 512.

15. Trautman, R., and M. Cowan. 1968. In Methods in Immunology and Immunochemistry, C. A. Williams and
M. W. Chase, editors. Academic Press Inc., New York. 2: 81 .

16. Markham, R. 1967. In Methods in Virology. K. Maramorosch and $\mathrm{H}$. Koprowski, editors. Academic Press Inc., New York. 2: 3.

17. Markham, R. 1967. In Methods in Virology. K. Maramorosch and $\mathrm{H}$. Koprowski, editors. Academic Press, Inc., New York. 2: 275.

18. Layne, E. 1957. Methods Enzymol. 3: 447.

19. Uriel, J. 1964. In Immunoelectrophoretic Analysis. P. Grabar and P. Burtin, editors. American Elsevier Publishing Co., New York, 30.

20. McGuckin, W. F., and B. F. McKenzie. 1958. An improved periodic acid fuchsin sulfite staining method for evaluation of glycoproteins. Clin. Chim. Acta . 4: 476.

21. Watson, D. H., W. C. Russel, and P. Wildy. 1963. Electron microscopic particle count on Herpes virus using the phophotungstate negative staining technique. Virology. 19: 250 .

22. Sharp, D. G. 1953. Purification and properties of animal viruses. Advan. Virus Res. 1: 277.

23. Bachrach, H. G., and C. E. Schwerdt. 1954. Purification studies on lansing poliomyelitis virus. II. Analytical electron microscopic identification of the infectious particles in preparations of high specific infectivity. J. Immunol. 72: 30 .

24. Kim, C. Y., and D. M. Bissell. 1970. Stability of lipid and protein of hepatitis-associated (Australia) antigen. J. Infect. Dis. 123: 470 .

25. Millman, I., L. A. Loeb, M. E. Bayer, and B. S. Blumberg. 1970. Australia antigen (a hepatitis-associated antigen) purification and physical properties. J. Exp. Med. 131: 1190 .

26. Kim, C. Y., J. Spano, and G. E. Clark. 1971. Use of pepsin-treated hepatitis-associated antigen in the production of precipitating antibody. J. Infect. Dis. 124: 411.

27. Kim, C. Y., and J. G. Tilles. 1971. Immunologic and electrophoretic heterogeneity of hepatitis-associated antigen. J. Infect. Dis. 123: 618.

28. LeBouvier, G. L. 1971. The heterogeneity of Australia antigen. J. Infect. Dis. 123: 671 . 